\title{
THE PETROLOGY OF AK6, BOTSWANA: IMPLICATIONS OF VOLCANIC AND IGNEOUS PROCESSES
}

\author{
RC Ogilvie-Harris ${ }^{1}$, M Field ${ }^{2}$, RA Brooker ${ }^{1}$, MJ Walter ${ }^{1}$ and RSJ Sparks ${ }^{1}$ \\ ${ }^{1}$ School of Earth Sciences, University of Bristol, Wills Memorial Building, Bristol, BS8 1RJ \\ ${ }^{2}$ DiaKim Consulting Limited, Wells, United Kingdom
}

\section{INTRODUCTION}

In this study the three intrusive lobes of the AK6 kimberlite in Botswana (Figure 1) are studied and the mineralogy is used to try and understand the different processes that have occurred in each lobe e.g. magma mixing, as well as the textural features that indicate a volcaniclastic origin.

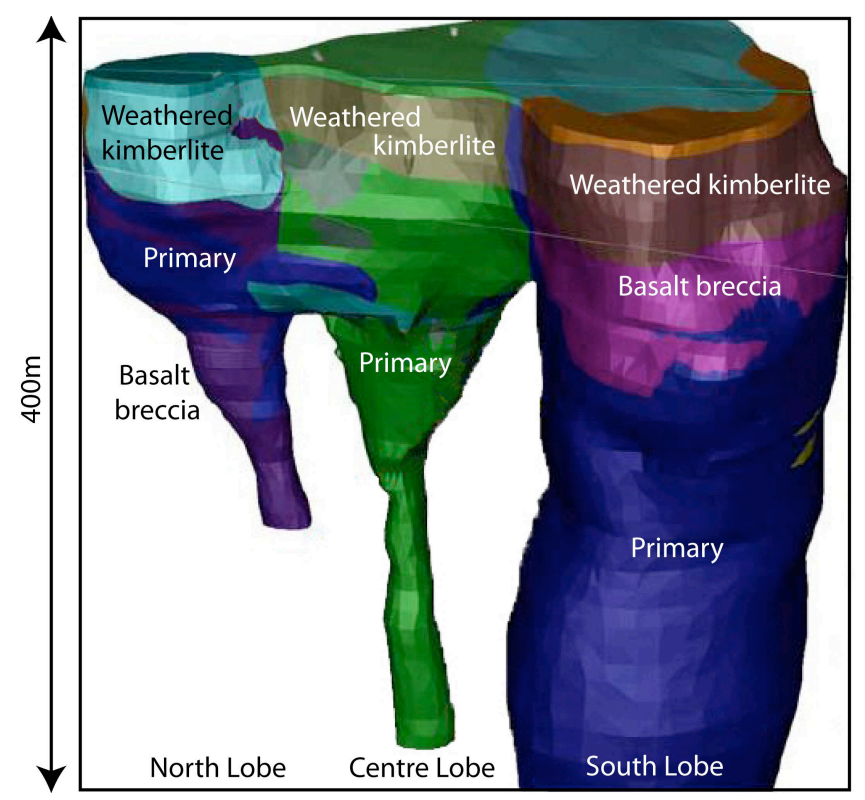

Figure 1. Diagram of AK6, adapted from McGeorge et al., (2010), with the geological units are looking north-east. The AK6 tri-lobate kimberlite pipe forms part of the Orapa cluster kimberlites in Central Botswana.

The AK6 pipe has two distinct types of kimberlite: firstly a dark kimberlite in the South lobe and a green-grey, more obviously volcaniclastic kimberlite in the North and Centre lobe. The South Lobe is also significantly different from the North Lobe and Centre Lobe in terms of petrology, geochemistry, density, pipe shape and the diamond populations.

\section{PETROLOGY}

\section{South Lobe kimberlite}

The South Lobe kimberlite is a poorly sorted, dark grey to black competent kimberlite that is olivine-rich, matrix- to clast-supported and contains country rock lithic clasts. Feature that are considered characteristic of a coherent kimberlite include fresh olivine, monticellite and a highly crystallized interstitial matrix of groundmass material (Hayman et al., 2008). This matrix is composed of small, euhedral olivine, zoned monticellite (up to $120 \mathrm{um}$ ), zoned perovskite, chromite spinel, Fe-Ti spinel, apatite, phlogopite and serpentine. There is little to no void filling material. However, it possesses some characteristics that are enigmatic to an intrusive rock. Lithic fragments from the deepest Archaean basement, basalt and Karoo sediments from the near surface are both evenly distributed throughout the whole pipe.

\section{North and Centre Lobe kimberlite}

The North and Centre Lobe kimberlites are poorly sorted, matrix-supported, green to grey coloured kimberlites that are much less competent than the South Lobe kimberlite. The olivine is partially to entirely serpenitinised. Some olivine macrocrysts and highly altered xenoliths are surrounded by the initial stages of magmatic selvages (Figure 2). The groundmass of both these kimberlites contains an abundance of opaques, zoned perovskite, apatite, phlogopite \pm psuedomorphed monticellite, \pm hydrogarnets and a matrix consisting of serpentine with minor calcite or diopside or serpentine with pools of calcite. Chlorite and clay can also be a component of the matrix. The high abundance of interstitial carbonate in the Centre Lobe kimberlite is the main feature that distinguishes it from the North Lobe. 


\section{$10^{\text {th }}$ International Kimberlite Conference, Bangalore - 2012}

into two main categories. The first (Group 1) are iron-poor $(6 \mathrm{wt} \%-10 \mathrm{wt} \% \mathrm{FeO})$ and the second
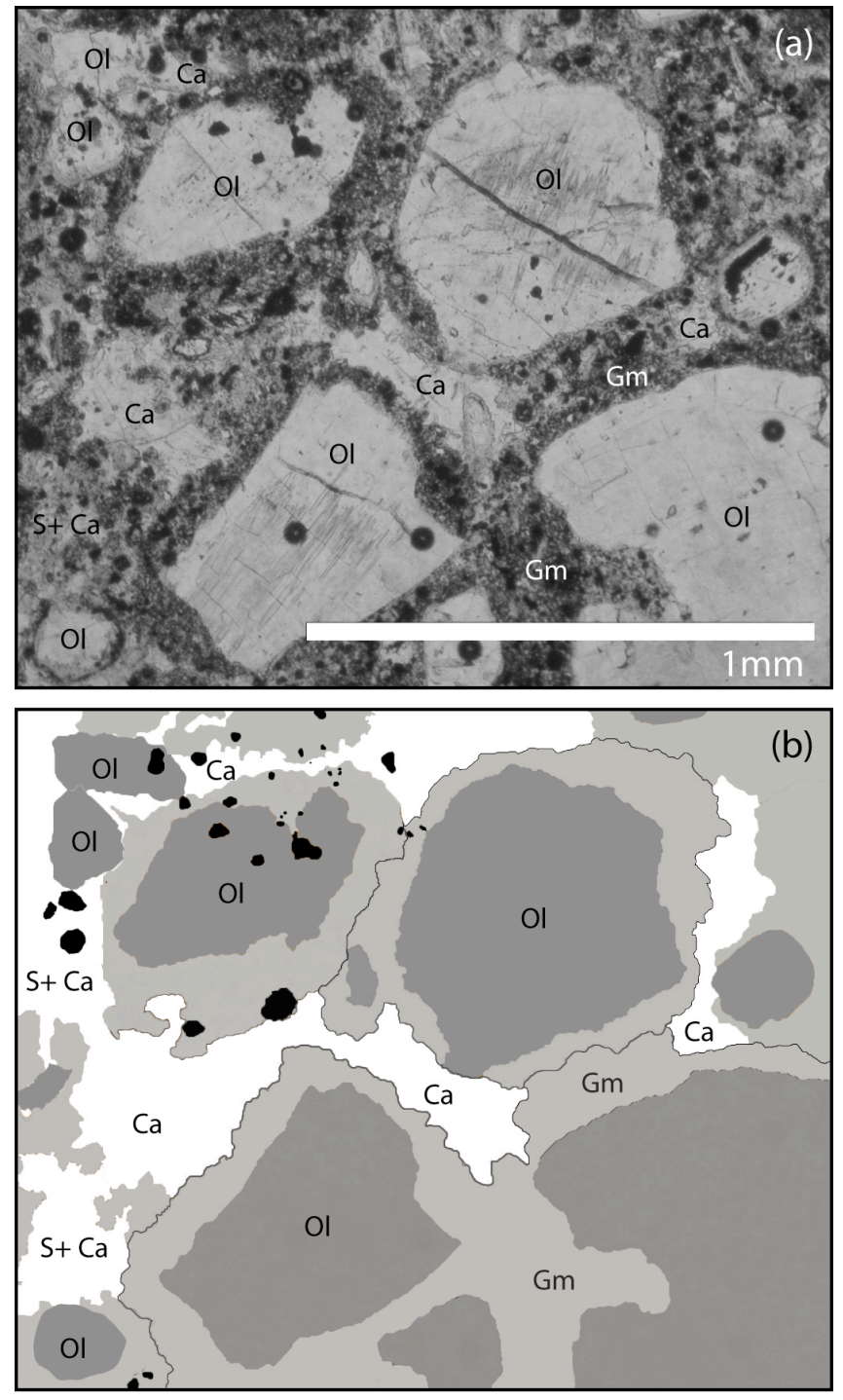

Figure 2. (a) Photomicrograph of the Centre Lobe kimberlite and (b) Cartoon of (a). Magmatic selvages full of oxides surround the psuedomorphed olivines. Irregularly shaped pools of oxide-free calcite and serpentine form the interstices between the olivine crystals. $\mathrm{Ca}=$ calcite; $\mathrm{S}=$ serpentine; $\mathrm{Ol}=$ olivine

\section{MINERAL COMPOSITIONS}

\section{Olivine}

The North and Centre Lobe olivines are rarely preserved, while fresh olivines in the South Lobe can be studied in detail. The olivine cores have variable fosterite (Fo) values ranging from $\mathrm{Fo}_{81}$ to $\mathrm{Fo}_{93}$, where as the Fo values remain fairly constant in the rims, between $\mathrm{Fo}_{86}$ and $\mathrm{Fo}_{87}$. As shown in Figure 3, the olivine cores tend to fall
(Group 2) iron-rich (14 wt\% to $18 \mathrm{wt} \% \mathrm{FeO})$. Both of these tend to be rimmed by olivine of a different composition, constantly between $12 \mathrm{wt} \%$ and $13 \mathrm{wt} \% \mathrm{FeO}$ (Group 4). There is also an intermediate olivine composition (Group 3) that occurs in select olivines between the core and rim, which have $\mathrm{FeO}$ contents between $11 \mathrm{wt} \%$ and $12 \mathrm{wt} \%$. The intermediate olivine composition occurs occasionally between the rims and both types of cores and as smaller euhedral groundmass olivines $(<500 \mathrm{um})$. These differences are also seen in the $\mathrm{NiO}$ contents, which range from 0.08 wt $\%$ to 0.43 wt $\%$.

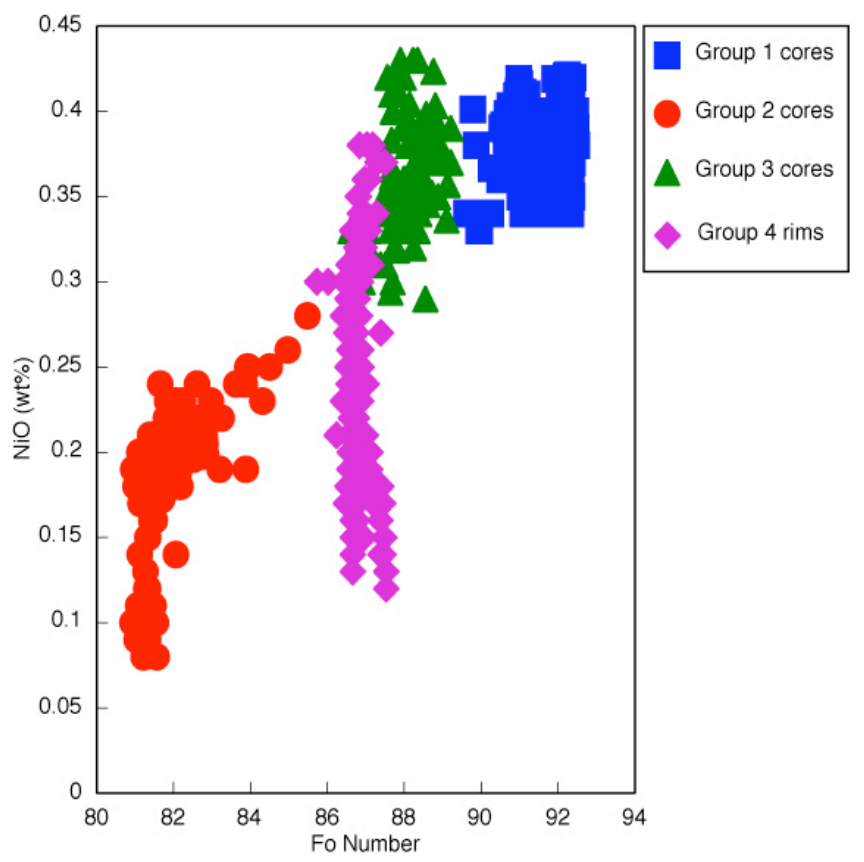

Figure 3. Plot showing the Fo number vs. NiO (wt\%). This plot shows four different olivine compositions: (i) Group 1, low $\mathrm{FeO}$, (ii) Group 2, high $\mathrm{FeO}$, (iii) Group 3, intermediate $\mathrm{FeO}$ and (iv) Group 4, rim composition.

\section{Monticellite}

The compositions of the South Lobe monticellite are discussed below as monticellite is rarely preserved in the North and Centre Lobes.

The monticellite tends to have Fe-rich cores and Fe-poor margins, with $\mathrm{FeO}$ contents ranging from $2.6-10.6 \mathrm{wt} \%$. However, normal zoning is also evident, where the cores are less enriched in $\mathrm{Fe}$ than the outer rim. The $\mathrm{Ca} /(\mathrm{Ca}+\mathrm{Mg}+\mathrm{Fe})$ ratio ranges from $0.45-0.5$ and $\mathrm{Fe} /(\mathrm{Fe}+\mathrm{Mg})$ ranges from $0.06-0.24$. Some monticellites with high Fe correlate with data from monticellite found in the Polino monticellite-calciocarbonatite (Stoppa and Lupini, 2004). 


\section{Spinel}

The North and Centre Lobe spinels differ from the South Lobe spinels (Figure 4). The South Lobe has two groups of spinels. Whilst both groups show $\mathrm{Fe}^{3+}$ increasing with increasing $\mathrm{Fe}^{2+} /\left(\mathrm{Mg}+\mathrm{Fe}^{2+}\right)$ up towards magnetite, the Group 2 spinels are more Fe-rich compared to Group 1. The difference is seen in $\mathrm{Fe}^{2+} /\left(\mathrm{Fe}^{2+}+\mathrm{Mg}\right)$, which is between 0.4 and 0.6 at low concentrations of $\mathrm{Fe}^{3+} /\left(\mathrm{Fe}^{3+}+\mathrm{Al}+\mathrm{Cr}\right)$.
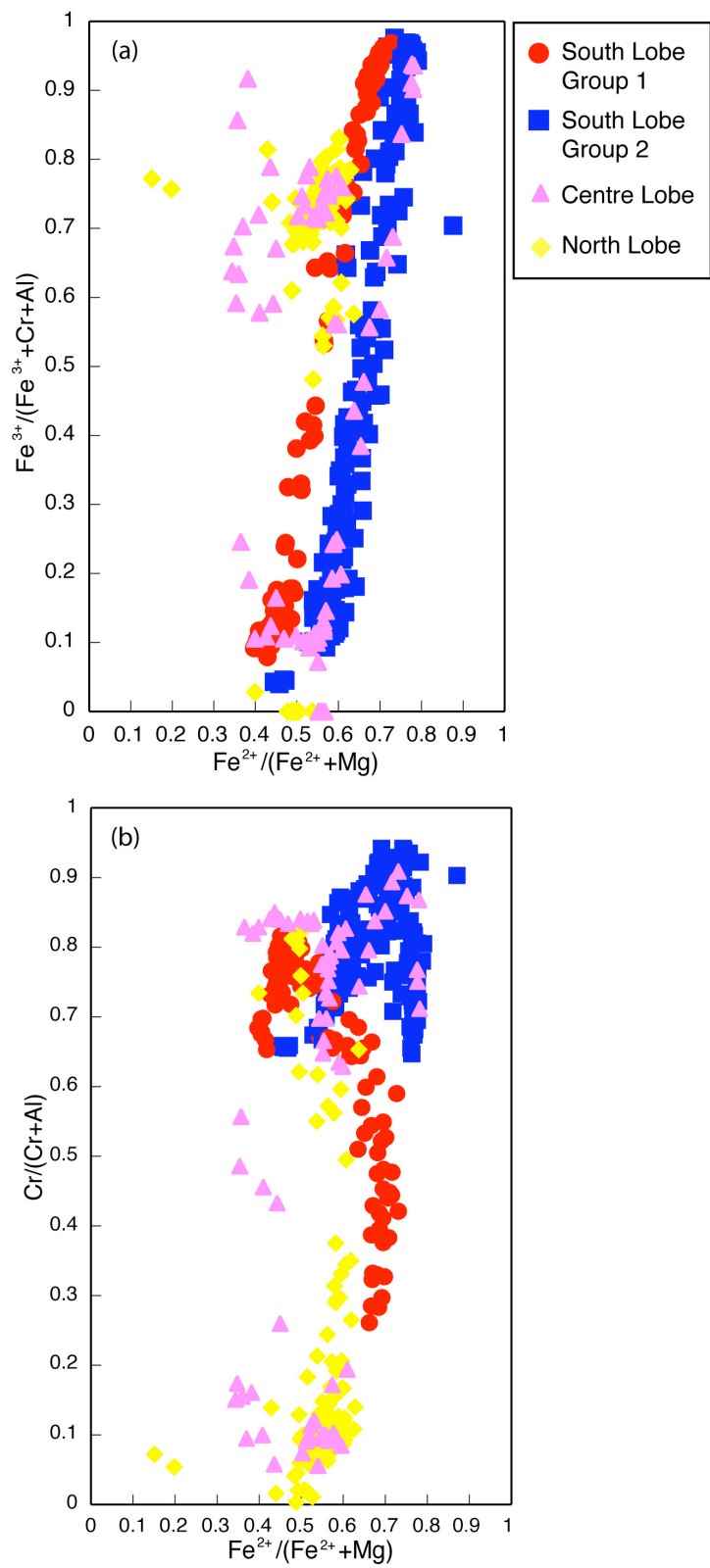

Figure 4. $\mathrm{Fe}^{2+} /\left(\mathrm{Fe}^{2+}+\mathrm{Mg}\right)$ vs (a) $\mathrm{Fe}^{3+} /\left(\mathrm{Fe}^{3+}+\mathrm{Al}+\mathrm{Cr}\right)$ and (b) $\mathrm{Cr} /(\mathrm{Cr}+\mathrm{Al})$ for spinel in the AK6 kimberlite
$\mathrm{Cr} /(\mathrm{Cr}+\mathrm{Al})$ is also significantly different between these two groups. In Group $1, \mathrm{Cr}$ decreases significantly as $\mathrm{Fe}$ increases, from 0.8 to 0.2. However, the change in Group 2 is not as extensive, over the $\mathrm{Cr} /(\mathrm{Cr}+\mathrm{Al})$ ranges from 0.6 0.95 . Group 2 spinels compositions are intermittently found crystallized on the edge of the Group 1 crystals.

Most of the spinel in the North and Centre Lobe are titanomagnetites; some are partially altered to hydro-garnets (mainly in the Centre Lobe). Occasionally, rare large $\mathrm{Cr}$ spinels can be found that have similar compositions to both Group 1 and Group 2 in the South Lobe.

\section{Perovskite}

Perovskites in the South Lobe are significantly different from the North Lobe and Centre Lobes (Figure 5), which have very similar compositions. The Centre and North Lobe perovskites have significantly higher $\mathrm{Ce}(1.8-3.3$ wt $\left.\% \mathrm{Ce}_{2} \mathrm{O}_{3}\right)$ and $\mathrm{Nb}\left(0.7-1.7 \mathrm{wt} \% \mathrm{Nb}_{2} \mathrm{O}_{5}\right)$ compared to the South Lobe $\left(0.1-2.4 \mathrm{wt} \% \mathrm{Ce}_{2} \mathrm{O}_{3}\right.$ and $0.3-0.9 \mathrm{wt} \%$ $\mathrm{Nb}_{2} \mathrm{O}_{5}$ ), although the rim $\mathrm{Ce}$ and $\mathrm{Na}$ content are must closer in value compared to the North and Centre lobes.
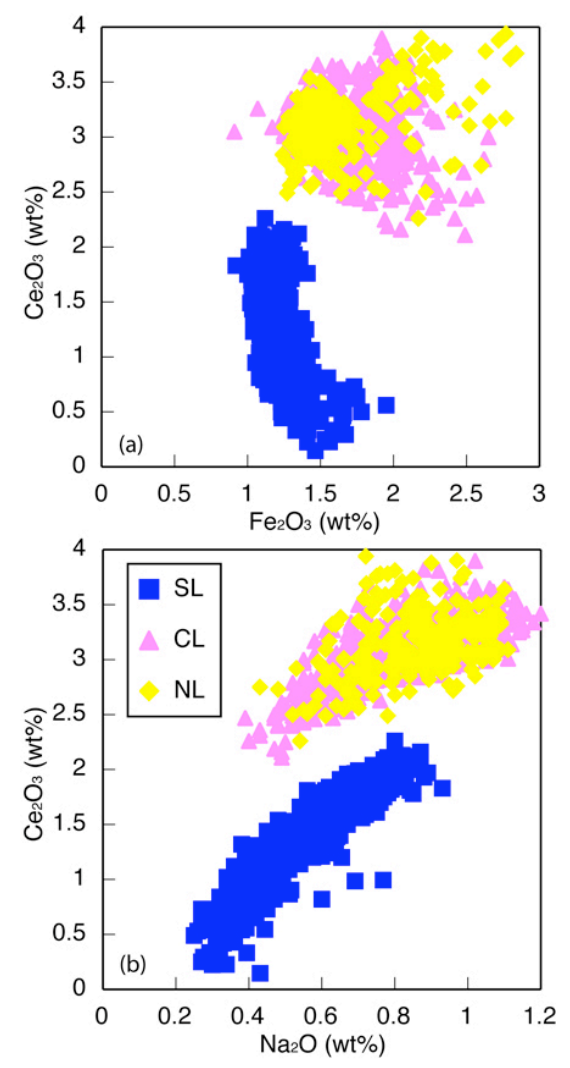

Figure 5. Plot showing (a) $\mathrm{Fe}_{2} \mathrm{O}_{3}$ (wt\%) and (b) $\mathrm{Na}_{2} \mathrm{O}$ vs $\mathrm{Ce} 2 \mathrm{O} 3$ (wt \%) in perovskite. The South Lobe is significantly different to the North and Centre lobes, which are indistinguishable from each other and more 


\section{$10^{\text {th }}$ International Kimberlite Conference, Bangalore - 2012}

\section{DISCUSSION}

The South Lobe is characterised by: (1) fresh zoned olivine with two distinct core compositions with rims of a similar composition; (2) abundant groundmass monticellite (generally unaltered); (3) high-Cr and low-Ti primitive spinels; (4) REE-poor, F-rich apatite; (5) REE- and Nb-poor perovskite; (6) little to no void filling material e.g. microlites or diopside; (7) comparatively little groundmass serpentine.

The Centre and North lobes are characterised by: (1) partially-to-completely serpentinised olivine, with some Fehydroxide alteration; (2) groundmass monticellite, typically psuedomorphed by serpentine; (3) titanomagnetite spinel partially altered to hydrogarnet; (4) REE-, Nb- and Fe-rich perovskite; (5) oxide-free calcite and/or serpentine segregations (occasionally containing microlites or radiating diopside); (6) REE-rich and F-poor (relative to the South Lobe) apatite; (7) groundmass containing common serpentine.

\section{Multiple magma batches and magma mixing}

The AK6 kimberlite shows evidence for multiple batches of magma by: i) the presence of the two distinct kimberlite types within one pipe and ii) range of mineral compositions within the South Lobe kimberlite.

The South Lobe olivine, monticellite and spinel each have distinct groupings defined by different compositions (see Figure 3 and 4). This is most apparent in the case of the olivines (and to some extent monticellite), which have two defined groups of cores (high $\mathrm{Fe}$ and low $\mathrm{Fe}$ ), all enclosed with the same rim compositions. Such features are commonly attributed to magma mixing (e.g. Luhr and Carmichael, 1980). Unfortunately, primary minerals, such as olivine and monticellite, have been highly altered within the North and Centre Lobes and therefore cannot be used for comparison.

Spinel in the South Lobe also shows two distinct groupings. Roeder and Schulze (2008) suggest that the different compositions of different batches of kimberlite magma can cause a variation in spinel compositions. Spinels from Group 1 are not as common as Group 2 and occasionally are mantled by spinels with compositions of Group 2, but not vice versa. This infers that Group 1 spinels crystallized prior to the crystallisation of Group 2 from a different magma.

While the South Lobe kimberlite crystallizes spinels that have a Cr-rich core and Fe-rich rims, the North and Centre lobe spinels are predominantly small discrete Mum crystals. Large zoned crystals with Cr-rich cores as seen in the South Lobe are uncommon. This is most likely a growth feature
Perovskite also differs significantly between the South Love and the North and Centre Lobes. The North and Centre Lobes are more enriched in LREE and $\mathrm{Fe}^{3+}$ compared to the South Lobe. Chakhmouradian and Mitchell (2000) observed that high contents of LREE, Th and $\mathrm{Nb}$ in perovskite was not exclusive to any specific type of kimberlite but a merely the result of a kimberlitic magmas becoming enriched in such elements. The clear differnce in perovskite composition and LREE, $\mathrm{Nb}$ and $\mathrm{Fe}^{3+}$ contents indicate a different magma source for the perovskite to crystallize from.

\section{Welding}

The South Lobe groundmass is devoid of calciteserpentine filled interstices, because the pelletal clasts have completely coalesced forming patches of igneous-textured material. These textural criteria suggest that the South Lobe should be interpreted as a densely welded rock due to its uniformly dense nature. Such welded rocks have been recognized in other kimberlites that are also part of the Orapa cluster (e.g. B/K9) and at Venetia (Brown et al., 2008; Buse et al., 2011). The hot clasts sinter together at the point contacts and then deform to reduce pore space (Brown et al., 2008). Compared with the other lobes, a greater depth in the South Lobe results in a more dense kimberlite becomes with a higher amount of preserved primary minerals i.e. monticellite. Magma deeper in the conduit can experience more compaction from a heavier overburden causing the minerals to be squashed together removing any void space and therefore.

The North and Centre Lobes are interpreted as incipiently welded kimberlites. The pelletal clasts have thin envelopes of earlier melt inferring different eruption dynamics between the South Lobe and the North and Centre Lobes. The hot clasts sinter together at the point clasts. However, there is minimal deformation of the pelletal clasts, creating pore space. The irregular calcite and serpentine patches (Figure 2) represent the infilled pore space (Brown et al., 2008). This also allows later fluids to alter primary minerals such as olivine.

\section{References}

Brown, R. B., Buse, B., Sparks, R. S. J. and Field, M. (2008). On the welding of pyroclastics from very low-viscosity magmas: examples form kimberlite volcanoes. Journal of Geology 116, 354-374

Buse, B., Sparks, R. S. J., Field, M., Schumacher, J. C., Chisi, K. and Tlhaodi, T. (2011). Geology of the BK9 kimberlite (Damtshaa, Botswana): implications for the formation of dark volcaniclastic kimberlite. Bulletin of Volcanology 73, 1029-1045

Chakhmouradian, A.R. and Mitchell, R.H. (2000). Occurence, alteration patterns and compositional variation of perovskite in kimberlites. Canadian Mineralogist 38, 975-994 
Field. M. and Scott Smith, B. H. S. (1999). Contrasting geology and nearsurface emplacement of kimberlite pipes in Southern Africa and Canada. In International Kimberlite Conference, 7th (Cape Town, South Africa, 1999), Proc., 214-237

Hayman, P. C., Cas, R. A. F., Johnson, M. (2008) Difficulties in distinguishing coherent from fragmental kimberlite: a case study of the Muskox pipe (Northern Slave Province, Nunavut, Canada). Journal of Volcanology and Geothermal Research 174, 139-151

Luhr, J.F. and Carmichael, I.S.E. (1980) The Colima volcanic complex, Mexico I. Post-caldera andesites from Volcán Colima. Contributions to Mineralogy and Petrology, 71, 343-372.

McGeorge, I., Lynn, M., Ferreira, J., Croll, R., Blair, D and Morton, K. (2010). NI 43-101 Technical Report revision and update on the AK6 Kimberlite Mine, Botswana.

Mitchell, R.H. (1986). Kimberlites: mineralogy, geochemistry and petrology. Plenum Press, New York

Roeder, P.L. and Schulze, D.J. (2008). Crystallization of groundmass spinel in kimberlite. Journal of Petrology 49, 1473-1495

Sparks, R.S.J., Baker, L., Brown, R. J., Field, M., Schumacher, J., Stripp, G. and Walters, A. (2006). Dynamical constraints on kimberlite volcanism. Journal of Volcanology and Geothermal Research 155, 1848

van Straaten, B. I., Kopylova, M. G., Russell, J. K., Webb, K. J. and Scott Smith, B. H. (2009). Stratigraphy of the intra-crater volcaniclastic deposits of the Victor Northwest kimberlite, northern Ontario, Canada. Lithos 112S, 488-500 